\title{
Food neophobia in children
}

\author{
Neofobia żywieniowa u dzieci
}

\author{
Paulina Łoboś, Anna Januszewicz
}

Postgraduate studies - Psychodietetics, SWPS University of Social Science and Humanity, Wroclaw, Poland

\begin{abstract}
Eating habits are formed from the early childhood through experience gained from the contact with foods and as a result of observation of the environment. One of the feeding disorders, specific for the childhood, is food neophobia, defined as an attitude towards food, which manifests as a persistent reluctance to eat new foods, avoiding tasting unknown products and unwillingness to accept newly introduced flavours or unknown consistency of food. It should be differentiated from pickiness, which are a typical stage of children's development. Food neophobia is a significant problem from both psychological and dietary perspective. The mechanism conditioning the onset of food neophobia has not been fully understood. It can be determined by the combination of biological, psychological and environmental factors, which include: various genetic conditions, individual personality predispositions, the level of child's familiarity with the taste, the moment and the method of introducing new products and parents' attitude towards food. The health consequences of food neophobia refer mainly to the potential loss of benefits due to an imbalanced diet and reducing the consumption of products rich in valuable nutrients. The severity of food neophobia determines the way of feeding children, forming their eating habits for further life.
\end{abstract}

Key words:

children, food neophobia, picky/fussy eating, feeding difficulties, selective eating.

\section{Streszczenie}

Nawyki żywieniowe są kształtowane już od wczesnego dzieciństwa na drodze doświadczeń zdobywanych w kontakcie z poszczególnymi pokarmami oraz w wyniku obserwacji zachowań powielanych przez otoczenie. Jednym z zaburzeń karmienia, charakterystycznym dla okresu dzieciństwa, jest neofobia żywieniowa, definiowana jako postawa wobec jedzenia, która polega na utrzymującej się niechęci do spożywania nowych pokarmów, unikaniu próbowania nieznanych produktów oraz braku otwartości na zaakceptowanie odmiennych niż dotychczas smaków czy nieznanej konsystencji pożywienia. Należy ją różnicować z wybrzydzaniem lub grymaszeniem, które stanowią charakterystyczny etap rozwoju dzieci. Neofobia żywieniowa stanowi istotny problem zarówno z psychologicznego, jak i dietetycznego punktu widzenia. Mechanizmy warunkujące wystąpienie neofobii żywieniowej nie zostały dotychczas w pełni poznane. Zjawisko to może być determinowane przez współoddziaływanie czynników biologicznych, psychologicznych i środowiskowych, do których zaliczane są m.in.: różnego rodzaju uwarunkowania genetyczne, indywidualne predyspozycje osobowościowe, poziom znajomości danego smaku przez dziecko, moment i sposób wprowadzania nowych produktów oraz postawa rodziców wobec jedzenia. Konsekwencje zdrowotne neofobii żywieniowej odnoszą się przede wszystkim do potencjalnie utraconych korzyści z powodu mało urozmaiconej diety i ograniczenia spożycia grup produktów bogatych w wartościowe składniki odżywcze. Nasilenie neofobii żywieniowej warunkuje bowiem sposób żywienia dzieci, kształtując ich nawyki żywieniowe na dalsze życie.

Słowa kluczowe:

dzieci, neofobia żywieniowa, grymaszenie, zaburzenia karmienia, wybiórcze jedzenie. 


\section{Food neophobia versus fussy eating}

Food neophobia is defined as the attitude towards food which consists in reluctance to eat new foods and avoidance of trying unknown products [1-6]. This phenomenon belongs to the group of Avoidant/Restrictive Food Intake (ARFID) disorders, which belong to a wider group, i.e. sensory food aversions $[1,3,7,8]$. The essence of neophobic behaviour is a clear, persistent reluctance, and sometimes even fear of tasting new food and lack of openness to accept different than before tastes or unknown consistency and/or colour of food. This rejection may also apply to products previously eaten, which only look new when served in a different form than usual [1, 4-7]. The strong emotional reactions caused by exposure to unknown food and the fact that the treatment of these disorders is based on familiarization with the object causing anxiety confirm that food neophobia may be classified into a group of phobias $[3,7,8]$.

Pickiness or fussiness (also referred to as a picky/fussy attitude) is an approach to eating that means rejecting food products not only when they are tasted for the first time, but also when they have been already known and accepted. In fussy children, more often not only the range of foods is much more limited, but also the amount of food consumed in general than in those that manifest neophobic behaviour [1, 3, 6, 7, 9-12]. Picky/fussy behaviour is most often temporary and is characteristic for children aged about 2-3 years. This phenomenon is a natural stage of development of children seeking a way to manifest their autonomy $[1,5-7,9-11,13]$. The Pelchat and Pliner study indicated that neophobic behaviour may be partially contained in the picky/fussy attitude, whereas pickiness is not considered a component of food neophobia, due to the fact that fussy children are not so resistant to learning new tastes, but are only generally reluctant to eat specific food [14].

\section{Presumed pathomechanism of developing neophobic behaviours towards food}

The mechanism determining the occurrence of food neophobia has not yet been fully recognised. This phenomenon is determined by the interaction of many complex factors, the most important of which are biological, psychological and environmental factors [2-7, 9, 11, 15-20].

Neophobic behaviour used to have an important adaptive function in the past. The tendency to avoid unknown products was a natural protection of omnivorous species against consuming poisonous food [1, 3, 7, 16, 21]. Negative experiences gained during exposure to new food products may be the cause of the strengthening of the inborn neophobic attitude. In children with high levels of food neophobia, a higher tendency to reject new kinds of food is often observed only on the basis of individual sensory perception of food-related stimuli - mainly by sight and smell, and to a lesser extent by touch - without an attempt to taste the food [4, 18, 22-27]. Then, a personal vision of how food products considered safe should look and smell is formed. Any deviation from this pattern results in an unwillingness to eat a gi- ven food [2-4, 7, 16, 18, 22-27]. This correlation has been confirmed in studies indicating that green vegetables, due to their colour, are much more frequently rejected by children than orange or red fruits [28-30]. If the food is assessed as acceptable, it is possible to try it, and the experience gained in this way (perceived by the individual as positive or negative) shapes the attitude towards a particular product in the future $[2-4,7,16,27,31]$.

\section{Food neophobia determinants}

On the basis of many scientific analyses, it can be assumed that food neophobia is a genetically determined condition. Numerous studies have also confirmed that a high level of neophobia in the mother was correlated with a higher neophobia of children, especially daughters [1, 3-6, 15, 32, 33]. However, in the majority of studies conducted so far, no differences in the prevalence of food neophobia diagnosis according to gender were observed $[1,7,15]$.

The incidence of food neophobia is determined by age, and its development is considered the highest at 2-6 years of age $[4,7,15,34]$. During puberty and adulthood, the risk of developing this attitude towards food significantly decreases, while in older age it increases again, which is explained by the fact that neophobic behaviours may potentially protect the weakened organism from possible poisoning due to old age $[1,7,15]$. The Kozioł-Kozakowska, Jagielski and Schlegel-Zawadzka studies analysing the prevalence of food neophobia in the population of Polish children at preschool age showed that this attitude is observed in one in ten children [35].

Another factor conditioning the attitude towards eating is personality. Numerous studies have shown a positive correlation between high levels of food neophobia and low openness to experience, anxiety and neuroticism. It has been also observed, that there is a positive correlation between shyness and emotional instability in children and the intensity of neophobic behaviours towards food $[1,4,7,36]$.

One of the early mechanisms for adapting to human living conditions is an innate predilection for sweet and salty tastes and aversion to bitter and sour substances, which are perceived as a warning against potential poisoning. Sensitivity to bitter taste is genetically determined, and the intensity of its perception depends on the number of taste buds on the tongue. The level of acceptance of new food products in which this taste is predominant may therefore be to some extent determined by the individual degree of sensitivity to bitterness. This may potentially contribute to shaping the neophobic attitude towards specific types of food, especially those with a distinctly bitter taste $[1,4$, $11,18,21,32]$. Many analyses have shown that vegetables are the most frequently rejected group of products due to hypersensitivity to bitter taste $[3,7,11,32,37]$.

Early taste experiments, both fetal and neonatal, may significantly affect later individual taste preferences. During the consumption of breast milk, the infant has the possibility to feel various tastes, depending on the type of food chosen by the mother. This contributes to a greater acceptance of new products 
introduced into the diet, especially in relation to food products that the mother regularly consumed during pregnancy and lactation. Children fed with modified milk tend to get used to a constant, specific taste of the mixture and, as a consequence, more often show reduced tolerance or even aversion during exposure to new types of food $[4,7,11,16,20,21,27,38-41]$. One study by Mennella, Jagnoew and Beauchamp found that children whose mothers consumed carrot juice in the third trimester of pregnancy and/or during breastfeeding were more likely to eat carrot puree when it was being introduced into the diet in infancy compared to children of mothers who did not drink carrot juice during pregnancy and/or lactation [42]. Similar conclusions were presented in the Hepper [43] and Schaal, Marlier and Soussignan [44] studies. Attitude towards food depends on a child's level of knowledge of a given product. Many studies have confirmed that children are much more likely to choose food in the future that they have ever had contact with and that they are familiar with to some extent [38-42]. In the Pliner and Stallberg-White study, it was observed that the addition of a favourite sauce to a new dish contributed to the fact that children tasted it more willingly than the same unknown dish without sauce [45].

The child's reluctance to eat certain food products may also be conditioned by the late introduction of new products into the diet. Openness to taste unknown flavours is highest in infants up to 12 months of age and decreases with age [7, 18, 20, 40, $46,47]$. Moreover, too fast resignation from continuing exposure to the new product after the initial negative reaction of the child may result in the necessity to eliminate this food from the daily diet. Many studies have shown that only about $10-15$ positive experiences gained through numerous patient exposures to specific products may result in the acceptance of the product $[16,20,32,46,47]$. Many analyses also emphasized the role of sensory perception of new food as a method supporting the familiarization with the look, consistency and texture of unknown products, which in consequence may weaken the reluctance to eat them in future life $[1,7,22,23,48-51]$

The important role of caregivers in shaping proper eating habits in children has been confirmed in many scientific analyses [1-7, 11, 16, 17, 20, 31, 47, 52-67]. Children's eating attitudes are shaped by observation and imitation of behaviours and reactions of the surrounding people $[1,3,4,7,11,13,17,20$, 21, 31, 52]. Harper and Sanders's study showed that children were much more likely to try an unknown food when at the same time their mothers also ate the product and reacted enthusiastically to it. This effect was stronger than in the case when the parent only verbally encouraged the child to try the food [53]. Similar conclusions were also drawn in other studies [54-57]. Van der Horst's analysis showed, however, that the involvement of children in the meal preparation process can reduce the intensity of neophobic behaviors and contribute to building positive experiences with food [58]. In a study conducted among older children, it was also observed that the nutritional choices of children may be significantly influenced by their peers [32, 59-62].

Parent pressure, as well as forcing children to eat disliked foods and punishing them if they refuse to eat can result in increased reluctance to food. Many studies have confirmed that the more authoritative the parents are towards the child during a meal, the more often the child rejects the offered products [17, 32, 33, 52, 63-65]. It has been shown that when children are forced to eat food that they do not want, they start to feel anxiety and tension and their disgust with the product increases. This contributes to the development of negative associations related to the consumption of meals and leads to the exacerbation of neophobic behaviours [3, 4, 7, 11, 20, 31-33, 52, 57, 63-65]. This is consistent with the conclusions of the Rigal et al. study, which found that the difficulty of feeding children aged 20-36 months was mainly due to parents' overauthoritarian coercive practices aimed at forcing the child to consume the rejected food. Interestingly, the authors also pointed out that a permissive feeding style in which the parents satisfy all the child's wishes to avoid food conflicts does not increase the child's willingness to try the product. However, it was emphasized, that it is not possible to indicate the occurrence of a cause and effect relationship in this area, because it is difficult to clearly define whether the parental style determines the child's reaction during feeding, or whether the rejection of food by the child influences the occurrence of a specific behaviour in the parent [66].

It is also a common mistake for parents to impose their own taste preferences on their children, which manifests itself in refraining from giving children products that their caregivers do not like. This prevents the child from learning about various types of food and developing individual dietary preferences [3, 4, $7,11,17,31,40,47,52,62,67]$

\section{The potential impact of food neophobia on health}

Neophobic behaviours significantly determine children's eating habits, which has a significant impact on the quality of their diet in future life $[1,3,6,9,10,15,19]$. The health consequences of food neophobia are mainly related to the potentially lost benefits due to an imbalanced diet and reducing the consumption of groups of products rich in valuable nutrients [1, 3, 7, 9, 10, 19]. Proper nutrition in early childhood determines the optimal physical and mental development of children and contributes to the reduction of the risk of the occurrence of serious diet-related diseases in the future $[1-3,9,16,19]$.

The occurrence of neophobic behaviours in children with allergies, food intolerances, diabetes mellitus and other diseases requiring special dietary recommendations is also an important nutritional problem. The reluctance to try new products, which are an essential element of treatment, may exacerbate the course of the disease [1,3].

On the basis of the analyses conducted so far, it is not possible to clearly determine the influence of food neophobia on the state of nutrition of children, however, in most studies there is no correlation between the occurrence of food neophobia and reduced body weight in children [68]. It is necessary to conduct further studies in this area in order to determine unambiguously the long-term effects of childhood food neophobia on human health in future life $[7,68]$. 


\section{References}

1. Kozioł-Kozakowska A, Piórecka B. Neofobia żywieniowa, jej uwarunkowania i konsekwencje zdrowotne. Stand Med Pediatr 2013; 1: 1-6.

2. Gibson EL, Cooke L. Understanding food fussiness and its impact for food choice, health, weight and interventions in young children: The impact of professor Jane Wardle. Curr Obes Rep 2017;6: 4656. doi: 10.1007/s13679-017-0248-9

3. Dovey TM, Staples PA, Gibson EL, et al. Food neophobia and 'picky/ fussy' eating in children: a review. Appetite 2008; 50: 181-193.

4. Blissett J, Fogel A. Intrinsic and extrinsic influences on children's acceptance of new foods. Physiol Behav 2013; 121: 89-95.

5. Smith AD, Herle M, Fildes A, et al. Food fussiness and food neophobia share a common etiology in early childhood. J Child Psychol Psychiatry 2017; 58: 189-196.

6. Cole NC, An R, Lee SY, et al. Correlates of picky eating and food neophobia in young children: a systematic review and meta-analysis. Nutr Rev 2017; 75: 516-532.

7. Lafraire J, Rioux C, Giboreau A, et al. Food rejections in children: Cognitive and social/environmental factors involved in food neophobia and picky/fussy eating behavior. Appetite 2016; 96: 347-357.

8. Bryant-Waugh R. Feeding and eating disorders in children. Psychiatr Clin North Am 2019; 42: 157-167.

9. Taylor CM, Wernimont SM, Northstone K, et al. Picky/fussy eating in children: Review of definitions, assessment, prevalence and dietary intakes. Appetite 2015; 95: 349-359.

10. Van der Horst K, Deming DM, Lesniauskas R, et al. Picky eating. Associations with child eating characteristics and food intake. Appetite 2016; 103: 286-293. doi: 10.1016/j.appet.2016.04.027

11. Scaglioni S, De Cosmi V, Ciappolino V, et al. Factors influencing children's eating behaviours. Nutrients 2018; 10: 706. doi: 10.3390/ nu10060706.

12. Brown SD. The rejection of known and previously accepted foods in early childhood. University of Birmingham Research Archive; 2010.

13. Ogden J. Rozwojowe modele wyborów żywieniowych. In: Psychologia odżywiania się. Od zdrowych do zaburzonych zachowań żywieniowych. Ogden J (ed.). Wydawnictwo Uniwersytetu Jagiellońskiego, Krakow 2011; 37-46.

14. Pelchat ML, Pliner P. "Try it. You'll like it". Effects of information on willingness to try novel foods. Appetite 1995; 24: 153-165.

15. Dematté ML, Endrizzi I, Gasperi F. Food neophobia and its relations with oflaction. Front Psychol 2014; 5: 1-6. doi: 10.3389/fpsyg. 2014.00127

16. Cooke L. Genetic and environmental influences on food neophobia. In: Food neophobia: Behavioral and biological influences. Reilly S (ed.). Woodhead Publishing Series in Food Science, Technology and Nutrition 2018; 237-254

17. Howard AJ, Mallan KM, Byrne R, et al. Toddlers' food preferences. The impact of novel food exposure, maternal preferences and food neophobia. Appetite 2012; 59: 818-825. doi: 10.1016/j.appet.2012.08.022

18. Ventura AK, Worobey J. Early influences on the development of food preferences. Curr Biol 2013; 23: 401-408. doi: 10.1016/j.cub. 2013.02.037

19. Johnson SL, Davies PL, Boles RE, et al. Young children's food neophobia characteristics and sensory behaviors are related to their food intake. J Nutr 2015; 145: 2610-2616. doi: 10.3945/jn.115.217299
20. De Cosmi V, Scaglioni S, Agostoni C. Early taste experiences and later food choices. Nutrients 2017; 9: 107. doi:10.3390/nu9020107.

21. Shutts K, Kinzler KD, DeJesus JM. Understanding infants' and children's social learning about foods: previous research and new prospects. Dev Psychol 2013; 49: 419-425. doi: 10.1037/a0027551

22. Wadhera D, Capaldi-Phillips ED. A review of visual cues associated with food on food acceptance and consumption. Eat Behav 2014; 15: 132-143; doi: 10.1016/j.eatbeh.2013.11.003.

23. Dovey T, Aldridge VK, Digman W, et al. Developmental differences in sensory decision making involved in deciding to try a novel fruit. Br J Health Psychol 2012; 17: 258-272. doi: 10.1111/j.20448287.2011.02036.x

24. Bunce C, Gibson EL. Sniffing, eating and disgust in food neophobic children. Appetite 2012; 59: 622. doi: 10.1016/j.appet.2012.05.047

25. Dematte ML, Endrizzi I, Biasioli F, et al. Food neophobia and its relation with olfactory ability in common odour identification. Appetite 2013; 68: 112-117. doi: 10.1016/j.appet.2013.04.021

26. Spence C, Levitan CA, Shankar MU, et al. Does food color influence taste and flavor perception in humans? Chem Percept 2010; 3: 68-84.

27. Nicklaus $S$. The role of food experience during early childhood in food pleasure learning. Appetite 2016; 104: 3-9. doi: 10.1016/j. appet.2015.08.022

28. Gerrish CJ, Mennella JA. Flavor variety enhances food acceptance in formula-fed infants. Am J Clin Nutr 2001; 73: 1080-1085. doi: 10. 1093/ajcn/73.6.1080

29. Harris G. Introducing the infant's first solid food. Brit Food J 1993; 95: 7-10. doi: 10.1108/00070709310045004

30. Koch C, Koch EC. Preconceptions of taste based on color. J Psychol 2003; 137: 233-242. doi: 10.1080/00223980309600611

31. Kaar JL, Shapiro ALB, Fell DM, et al. Parental feeding practice, food neophobia, and child food preferences: What combination of factors results in children eating a variety of foods? Food Qual Prefer 2016; 50: 57-64.

32. Kral TV, Rauh EM. Eating behaviors of children in the context of their family environment. Physiol Behav 2010; 100: 567-573. doi: 10.1016/j.physbeh.2010.04.031

33. Faith MS, Heo M, Keller KL, et al. Child food neophobia is heritable, associated with less compliant eating, and moderates familial resemblance for BMI. Obesity (Silver Spring) 2013; 21: 1650-1655. doi: 10.1002/oby.20369

34. McFarlane T, Pliner P. Increasing willingness to taste novel foods: effects of nutrition and taste information. Appetite 1997; 28: 227 238. doi: 10.1006/appe.1996.0075

35. Kozioł-Kozakowska A, Jagielski P, Schlegel-Zawadzka M. Neofobia żywieniowa a stan odżywienia dzieci w wieku przedszkolnym. Endokrynol Otyłość 2011; 2: 89-90.

36. Haycraft E, Farrow C, Meyer C, et al. Relationships between temperament and eating behaviours in young children. Appetite 2011; 56: 689-692. doi: 10.1016/j.appet.2011.02.005

37. Dinehart ME, Hayes JE, Bartoshuk LM, et al. Bitter taste markers explain variability in vegetable sweetness, bitterness, and intake. Physiol Behav 2006; 87: 304-313. doi: 10.1016/j.physbeh.2005.10.018

38. Birch L, Savage J, Ventura A. Influences on the development of children's eating behaviours: from infancy to adolescence. Can J Diet Pract Res 2007; 68: 45-56. 
39. Schwartz C, Scholtens P, Lalanne A, et al. Development of healthy eating habits early in life. Review of recent evidence and selected guidelines. Appetite 2011; 57: 796-807. doi: 10.1016/j.appet.2011. 05.316

40. Nicklaus S. Children's acceptance of new foods at weaning. Role of practices of weaning and of food sensory properties. Appetite 2011; 57: 812-815. doi: 10.1016/j.appet.2011.05.321

41. Cooke L, Fildes A. The impact of flavour exposure in utero and during milk feeding on food acceptance at weaning and beyond. Appetite 2011; 57: 808-811. doi: 10.1016/j.appet.2011.05.317

42. Mennella JA, Jagnow CP, Beauchamp GK. Prenatal and postnatal flavor learning by human infants. Pediatrics 2001; 107: E88. doi: 10.1542/peds.107.6.e88

43. Hepper P. Human fetal "olfactory" learning. International Journal of Prenatal and Perinatal Psychology and Medicine 1995; 7: 147-151.

44. Schaal B, Marlier L, Soussignan R. Human fetuses learn odours from their pregnant mother's diet. Chem Senses 2000; 25: 729737. doi: 10.1093/chemse/25.6.729

45. Pliner P, Stallberg-White C. "Pass the ketchup, please": familiar flavors increase children's willingness to taste novel foods. Appetite 2000; 34: 95-103. doi: 10.1006/appe.1999.0290

46. Wardle J, Herrera ML, Cooke LJ, et al. Modifying children's food preferences: The effects of exposure and reward on acceptance of an unfamiliar vegetable. Eur J Clin Nutr 2003; 57: 341-348. doi: 10.1038/sj.ejcn.1601541

47. Wardle J, Carnell S, Cooke L. Parental control over feeding and children's fruit and vegetable intake: How are they related? J Am Diet Assoc 2005; 105: 227-232. doi: 10.1016/j.jada.2004.11.006

48. Szajewska H, Socha P, Horvath A, et al. Zalecenia żywienia zdrowych niemowląt. Zalecenia Polskiego Towarzystwa Gastroenterologii, Hepatologii i Żywienia Dzieci. Stand Med Pediatr 2014; 11 : 321-338.

49. Mustonen S, Tuorilla $\mathrm{H}$. Sensory education decreases food neophobia score and encourages trying unfamiliar foods in 8-12-yearold-children. Food Qual Prefer 2010; 21: 353-360. doi: 10.1016/j. foodqual.2009.09.001

50. Nederkoorn C, Jansen A, Havermans RC. Feel your food. The influence of tactile sensitivity on picky eating in children. Appetite 2015; 84: 7-10. doi: 10.1016/j.appet.2014.09.014

51. Coulthard H, Sealy AM. Play with your food! Sensory play is associated with tasting of fruits and vegetables in preschool children. Appetite 2017; 113: 84-90. doi: 10.1016/j.appet.2017.02.003.

52. Mitchell GL, Farrow C, Haycraft E, et al. Parental influences on children's eating behaviour and characteristics of successful parentfocussed interventions. Appetite 2013; 60: 85-94. doi: 10.1016/j. appet.2012.09.014

53. Harper LV, Sanders KM. The effects of adults' eating on young children's acceptance of unfamiliar foods. J Exp Child Psychology 1975; 20: 206-214. doi: 10.1016/0022-0965(75)90098-3
54. Jansen A, Tenney N. Seeing mum drinking a "light" product: is social learning a stronger determinant of taste preferences acquisition than caloric conditioning? Eur J Clin Nutr 2001; 55: 418-411. doi: 10.1038/sj.ejcn.1601175

55. Lumeng JC, Patil N, Blass EM. Social influences on formula intake via sucking in 7 to 14-week-old-infants. Dev Psychobiol 2007; 49: 351-361. doi: 10.1002/dev.20221

56. Salvy SJ, Vartanian LR, Coelho JS, et al. The role of familiarity on modeling of eating and food consumption in children. Appetite 2009; 50: 514-518. doi: 10.1016/j.appet.2007.10.009

57. Mosli RH, Miller AL, Peterson KE, et al. Sibling feeding behavior: Mothers as role models during mealtimes. Appetite 2015; 96: 617620. doi: 10.1016/j.appet.2015.11.006

58. Van der Horst L. Overcoming picky eating. Eating enjoyment as a central aspect of children's eating behaviors. Appetite 2012; 58 : 567-574. doi: 10.1016/j.appet.2011.12.019

59. Greenhalgh J, Dowey AJ, Horne PJ, et al. Positive- and negative peer modelling effects on young children's consumption of novel blue foods. Appetite 2009; 52: 646-653. doi: 10.1016/j.appet.2009.02.016

60. Lumeng JC, Hillman $\mathrm{KH}$. Eating in larger groups increases food consumption. Arch Dis Child 2007; 92: 384-387. doi: 10.1136/adc. 2006.103259

61. Frazier BN, Gelman SA, Kaciroti N, et al. I'll have what she's having: The impact of model characteristics on children's food choices. Dev Sci 2012; 15: 87-98. doi: 10.1111/j.1467-7687.2011.01106.x

62. Van Ansem WJ, Schrijvers CT, Rodenburg C, et al. Children's snack consumption: role of parent, peers and child snack-purchasing behavior. Results from the INPACT study. Eur J Public Health 2015; 25: 1006-1011. doi: 10.1093/eurpub/ckv098

63. Webber L, Cooke L, Hill C, et al. Associations between children's appetitive traits and maternal feeding practices. J Am Diet Assoc 2010; 110: 1718-1722. doi: 10.1016/j.jada.2010.08.007

64. Cassells EL, Magarey AM, Daniels LA, et al. The influence of maternal infant feeding practices and beliefs on the expression of food neophobia in toddlers. Appetite 2014; 82: 36-42. doi: 10.1016/j. appet.2014.07.001

65. Fries LR, Martin N, van der Horst K. Parent-child mealtime interactions associated with toddlers' refusals of novel and familiar foods. Physiol Behav 2017; 176: 93-100. doi: 10.1016/j.physbeh. 2017.03.001

66. Rigal N, Chabanet C, Issanchou S, et al. Links between maternal feeding practices and children's eating difficulties. Validation of French tools. Appetite 2012; 58: 629-637. doi: 10.1016/j.appet.2011.12.016

67. Carruth BR, Skinner JD. Revisiting the picky eater phenomenon: neophobic behaviors of young children. J Am Coll Nutr 2000; 19: 771-780.

68. Brown CL, Vander Schaaf EB, Cohen GM, et al. Association of picky eating and food neophobia with weight: a systematic review. Child Obes 2016; 12: 247-262. doi: 10.1089/chi.2015.0189 